allow. As Prof. Seifriz emphasizes : "The laws of science as formulated by man are to be commended, even the worst of them, because of the influence they have on further speculation, but they are at best but speculations. . . . In this light must we view the cell theory. Flexibility in thinking comes through mellowness in character and greater willingness to view matters philosophically."

Is a less critical, though historically more detailed, article, in the recent issue of Current Science (7, No. 6, December 1938), Mr. E. W. Melson, of the Bausch and Lomb Optical Co., Rochester, New York, claims that the cell theory has been followed by such a wealth of confirmation that we are justified to-day in rating it as the most fundamental concept in the whole science of modern biology. He gives interesting facts concerning the aberrations on cells made by Hooke, Swammerdam, Malpighi, Van Leeuwenhoek and Wolff. They, together with others mentioned, collected much data concerning cells. They undoubtedly saw them and probably their nuclei; but the significance escaped them. Dutrochet published in the eighteen twenties much material which showed. his clear conception of the anatomical identity of the cell. In fact, it seems that it was Dutrochet's experiments on physiology which made the recognition of the cell as a structural, functional and developmental unit a necessity. But the nucleus was left out. Schleiden's greatest contribution rests on his recognition that increase in the size and number of cells is responsible for growth, and Schwann's his statement that "The elementary parts of all tissues are formed of cells in an analogous, though very diversified manner, so that it may be asserted that there is one universal principle of development for the elementary parts of organisms, however different, and that this principle is the formation of cells. . . ." But we feel, with Prof. Seifriz, that biologists tend to be incautious of the theory, especially in elementary biological teaching, and do not realize sufficiently that neither Schleiden nor Schwann had at their disposal present-day knowledge of nuclear structure, mitotic division and all the modern concepts in genetics and cytology.

\section{Evidential Value of Blood Groups in Litigation}

THE debate on the second reading of the Bastardy (Blood Tests) Bill, introduced by Lord Merthyr, which took place in the House of Lords on February 8, was no less noteworthy for the tribute paid by Viscount Dawson of Penn to the work of Mendel in the study of inheritance than for the cogency of the arguments with which his Lordship supported the objects of the legislation proposed. Clause 1 of the Bill states that in applications for affiliation orders a court may, and at the request of either party shall, order a test to be made of the blood of all three parties in the case. Lord Dawson's insistence on the urgent desirability of substituting objective evidence for the human and subjective in this class of legal action, which is peculiarly open to the danger of a miscarriage of justice $-a$ contention in which he was followed with characteristic vigour by Lord Raglan-will be welcomed by all who concur in the view that the scientifically attested fact is the surest guide to right judgment. At the same time his recapitulation of the scientific evidence, on which confidence in the blood group test is based, will both inform public opinion as to its potentialities, while removing certain popular misconceptions as to its scope by the emphasis laid on its limitations. It was pointed out by both Lord Merthyr and Lord Dawson that the blood test provides no more than negative evidence, that is evidence of non-paternity, to the extent, it is estimated, of 30 per cent of innocent men. In the course of the debate it was pointed out that the application of the test in this connexion had been widely adopted in other countries and its supporters "were culled not from the scientists of one country, but from the whole civilized world". "It was," it was said further, "a slur on the medicine and law of this country that we were so long in adopting something so completely proved". The Bill was referred for inquiry to a Select Committee of the House; but the Lord Chancellor in summing up the arguments, mostly of a practical nature, against adoption of the Bill, accepted Lord Dawson's scientific view as "completely reliable".

\section{New Explanation of the Great Glen Fault}

THE powerful dislocation which intersects Scotland in a north-east and south-west direction along the line of the Great Glen has usually been interpreted by geologists as a normal fault with a vertical downthrow on its south-eastern side. In an important paper read before the Geological Society of London on February 8, however, Dr. W. Q. Kennedy brought forward new evidence which leads him to believe the fracture as a strike-slip or wrench fault with a true lateral displacement of approximately 65 miles. It belongs, therefore, to the same class as the San Andreas rift of California and, like the latter, presumably extends downward at least to the base of the earth's granitic shell. This conclusion is supported by several independent lines of evidence. (a) The Great Glen fault belongs to the same system as the Strathconan, Ericht-Laidon and Loch Tay faults, all of which have proved lateral displacements of up to five miles. (b) It possesses characters unlike those of a normal fault but similar to other strike-slip dislocations (for example, singularly smooth, straight outcrop and abnormally wide shatter-belt). (c) It displaces the great north-south injection belt of the Moine Series for a distance of at least sixty miles. (d) It truncates the Strontian granite, the southern portion of which, according to the detailed structural evidence, is missing. The missing half, however, has now been identified in the Foyers granite, which outcrops on the other side of the fault some sixty-five miles to the north-east and is similarly truncated by the fracture. These two intrusions consist of identical rock-types and agree in all details of internal and external structure. This interpretation clarifies certain obscure features of Scottish geology and serves to explain the southern continuation of the Moine Thrust in Islay. The fault is still active but the main lateral movement appears to have been 
accomplished in Upper Devonian or Lower Old Red Sandstone times. The dynamical interpretation of the movement, moreover, indicates that the fault must have resulted from a regional compression which acted in a north and south direction. The fracture is, therefore, unrelated to any Caledonian pressure or tension, but formed as a result of early Hercynian pressure.

\section{British Industries Fair}

The British Industries Fair, 1939, will open on February 20. It is divided into two main sectionsone at London and the other at Birmingham; and the London section is again divided into two groups -one at Olympia and the other at Earl's Court. The number of overseas buyers who have intimated their intention to come to the Fair is six hundred more than last year and they are coming from no fewer than 66 countries. Holland heads the list, sending 607 compared with 465 last year. Belgium is second, 293 having accepted as against 245. Eire is sending 269 as against 207; Poland, 164 compared with 72; Czechoslovakia, despite recent happenings, 154 as against 37 ; Hungary, 110 as against 19 ; from Denmark there is a slight falling off, 105 compared with 112 ; and from Switzerland 96 are coming, as against 79 last year. The hardware and heavy industries section of the Fair will be held, as heretofore, at Castle Bromwich, Birmingham. At Earl's Court the main exhibits will be those of the textile and furnishing trades, and also an Empire section. At Olympia the trades exhibited will include chemicals (light and heavy), scientific instruments, photographic and cinematographic apparatus, radio apparatus and plastics, in addition to a large number of other industries, such as glass and leather, usually regarded as belonging to the category of light industries. Among the chemical exhibits, that of Imperial Chemical Industries, Ltd., repeats the practice, introduced by this firm last year, of showing only one major product at a time. Last year the subject was soda; this year it will be ammonia. Exhibits will be shown in six main groups : the use of ammonia in its anhydrous form; as ammonia liquor ; as ammonium compounds ; oxidized to nitric acid ; converted to cyanide; and converted to urea.

As in recent years, the scientific instruments section will form a prominent and notable part of the exhibits at Olympia. The national rearmament programme has naturally involved the production on an enormous scale of the scientific instruments needed for the control of the various major weapons of war-such as range finders, periscopes, gun sights, bomb sights and cameras. The latest type of antiaircraft searchlight will be shown in action, and forms a central feature of the composite stand of this section. It is perhaps not generally realized that the speeds of modern aircraft are such that the antiaircraft gun may have to be directed as much as two miles ahead to enable the projectile to hit the target. 'Predictors', which automatically calculate this position, are now in general use by anti-aircraft batteries. The War Office has given permission for an anti-aircraft predictor to be displayed and a staff sergeant will be in attendance to give the public information. A photographic apparatus will be shown, which enables a photographic record to be made of a 500-page book on only $30 \mathrm{ft}$. of film-an apparatus obviously of great potential use to libraries. Among other apparatus and instruments to be exhibited will be the latest cinematographic projector ; a new type of highly efficient loudspeaker of very small dimensions; a projection saccharimeter, which gives an image on the screen showing the percentage of sugar in various foods; and a recent form of dust counter-the 'thermal precipitator'.

\section{Methods in the Study of Man}

Numerous questions of general interest, but in their immediate bearing more nearly affecting those concerned with teaching and research in the study of man, were raised by Dr. Henry Balfour in his Frazer Lecture delivered at Liverpool in 1937 and recently issued in pamphlet form ("Spinners and Weavers in Anthropological Research". Oxford : at the Claren. don Press, 1938. Pp. 19). The science of anthropology is a relatively young science; but its progress in recent years has been remarkably rapid. This has been due largely to a vigorous growth of specialization. So much so, indeed, that not only has it brought about a condition which now renders it unwieldy for the individual, but as Dr. Balfour pointed out, there is a real danger that the major problem, the full comprehension of man's nature and potentialities, may be lost sight of, through increasing individual enthusiasm over one or other branch of the general science of anthropology. Dr. Balfour himself was convinced not merely that there is place for both the 'generalist' and the 'specialist', but in fact that there is a real need for their co-operation as a condition of orderly advance in the future development of the science. Metaphorically their relation is expressed in the title of Dr. Balfour's lecture. Taking as an example the methods employed in one of the departments of his own special branch of study, technology, he expounds how in his conception of the relation of the diverse methods of study, the 'spinner', the specialist, provides the threads of surely grounded data from which the weaver, the 'generalist', fashions the fabric of theory. Among the conclusions which follow from this conception to which Dr. Balfour referred, not the least significant is that which develops its bearing on the organization of the curriculum for the anthropological student.

\section{Archæological Interpretation and Modern Analogies}

Among other matters upon which Dr. Balfour touched as incidental to the main thesis of his Frazer Lecture, not the least interesting is the interpretation of archæological data in the light of reference to objects of the material culture and to the practices and beliefs of modern and still-surviving peoples of backward culture. He recalled the opportunity for such a comparison, which was lost irretrievably when the Tasmanians, a people still living the life of palæolithic man, were allowed to die out in the last century and themselves became the subjects of the archro- 